\title{
First record of the driftwood catfish Spinipterus acsi Akama \& Ferraris, 2011 (Siluriformes, Auchenipteridae) for Brazil, Juruá River, Amazon basin
}

\author{
Bárbara B. Calegari, ${ }^{1,2}$ Alberto Akama, ${ }^{3}$ Roberto E. Reis ${ }^{1}$
}

1 Laboratório de Sistemática de Vertebrados, Pontifícia Universidade Católica do Rio Grande do Sul. Av. Ipiranga 6681, 90619-900 Porto Alegre, RS, Brazil; barbara.calegari@gmail.com, reis@pucrs.br. 2 Department of Vertebrate Zoology, National Museum of Natural History, Smithsonian Institution, Washington, DC, 20560 USA. 3 Museu Paraense Emílio Goeldi, Setor de Ictiologia, Caixa Postal 399, 66040-170 Belém, PA, Brazil; aakama@gmail.com

Corresponding author: Bárbara B. Calegari, barbara.calegari@gmail.com

\begin{abstract}
Spinipterus Akama \& Ferraris, 2011 is a monotypic genus known only by the holotype of its single species $S$. acsi, described from a creek tributary to the Nanay River, in the Peruvian portion of the Amazon basin. A second specimen of this genus and species representing the first record of occurrence in Brazil is reported from the Juruá River, upper Amazon basin, Amazonas state.
\end{abstract}

Key words

Taxonomy; Ostariophysi; biodiversity; Neotropics.

Academic editor: Cristiano Luis Rangel Moreira | Received 14 June 2018 | Accepted 25 July 2018 | Published 31 August 2018

Citation: Calegari BB, Akama A, Reis RE (2018) First record of the driftwood catfish Spinipterus acsi Akama \& Ferraris, 2011 (Siluriformes, Auchenipteridae) for Brazil, Juruá River, Amazon basin. Check List 14 (4): 693-697. https://doi.org/10.15560/14.4.693

\section{Introduction}

Spinipterus Akama \& Ferraris, 2011 is a monotypic genus of Auchenipteridae, an inseminating family of Siluriformes known as driftwood catfishes. The auchenipterids represent a monophyletic family recognized by several features related to sexual dimorphism, such as the possession of an intromittent organ in mature males and modifications on the fins and maxillary barbel during reproductive season (Ferraris and Vari 1999, Birindelli 2014, Calegari et al. 2014). The family currently comprises 120 species arranged in 22 genera (Eschmeyer et al. 2018, updated), Spinipterus being the most recently described. This genus was described based solely on the holotype from a creek tributary to the Nanay River in Peru. Some members of the Auchenipteridae are difficult to collect due to their behavior of lurking inside crevices in dead submerged logs, which require specific efforts beyond the traditional methods to collect them. Consequently, some species of Auchenipteridae, mainly centromochlines, are poorly represented in fish collections. Recently, a specimen of Spinipterus acsi Akama \& Ferraris, 2011 was discovered and identified in a museum fish collection, which was collected in the Juruá River, upper Amazon basin. So far, this specimen represents the second known individual of this species and the first record for Brazil. 


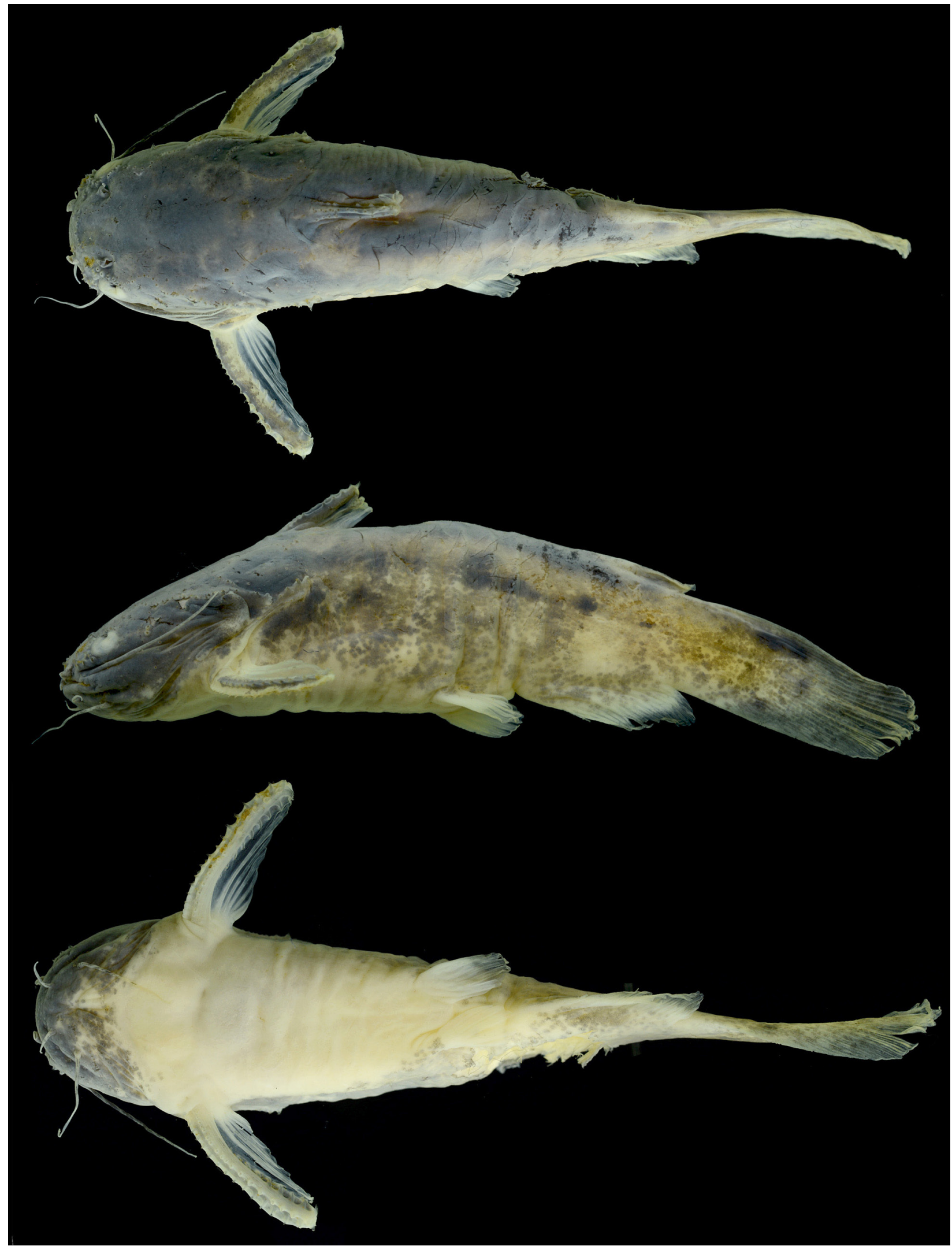

Figure 1. Spinipterus acsi, UFRGS 21671, male, 37.1 mm SL, Juruá River, upper Amazon basin, Brazil.

\section{Methods}

The specimen of Spinipterus acsi (Fig. 1) is deposited in the fish collection of the Universidade Federal do Rio Grande do Sul, Porto Alegre (UFRGS), Brazil. Mea- surements were made point-to-point and recorded to $0.1 \mathrm{~mm}$, following Lundberg and McDade (1986), with modifications introduced by Akama and Ferraris (2011). Morphometric data are expressed as percent of the standard length (SL), except subunits of the head, which 


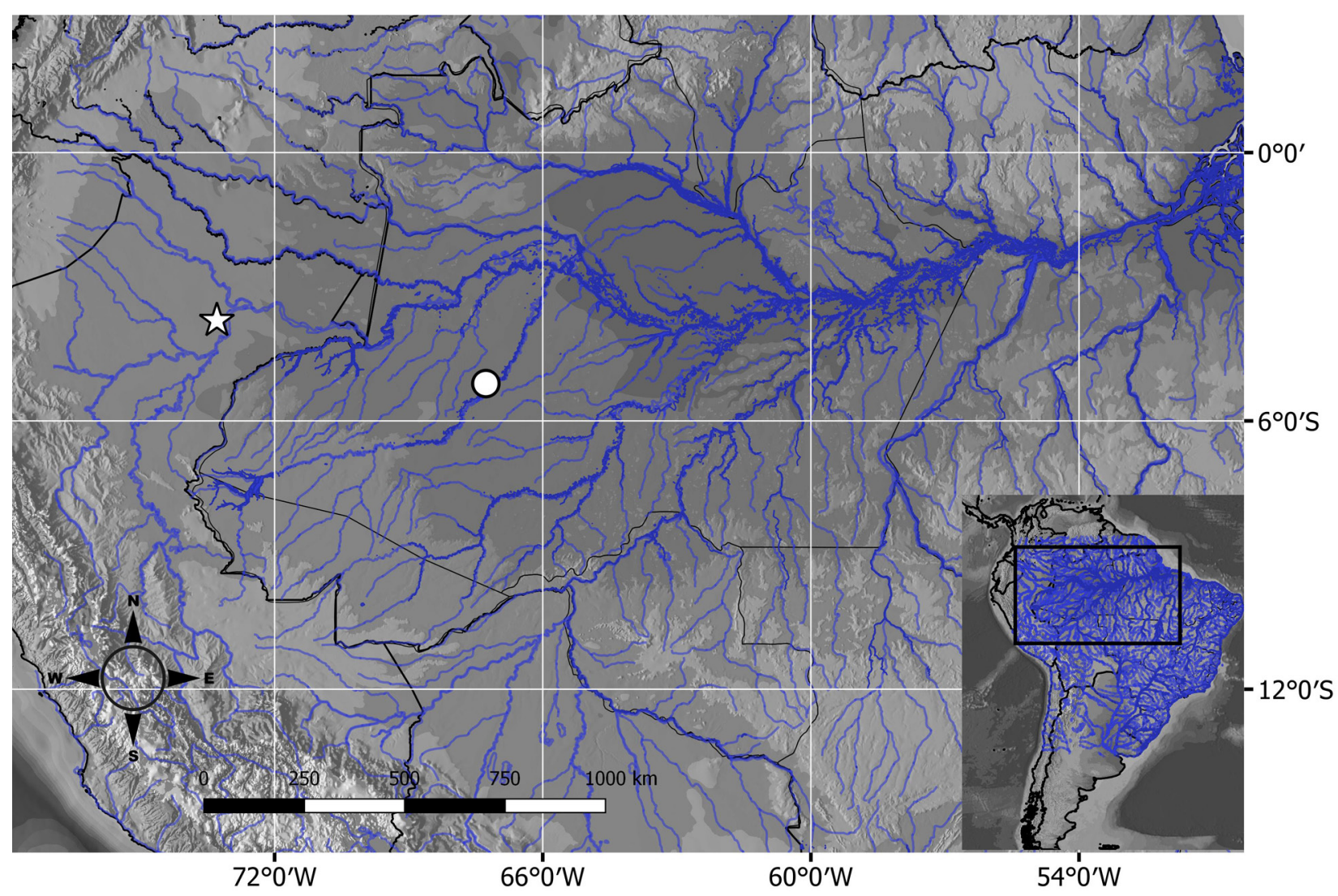

Figure 2. Type locality of Spinipterus acsi (ANSP 178209) in the Nanay river basin, upper Amazon, Peru (star) and the new specimen (UFRGS 21671) from the Cachimbo creek, tributary to Bauana Branco, Juruá River, upper Amazon basin, Carauari, Amazonas, Brazil (dot).

are expressed in percent of head length (HL). The geographic distribution map was prepared using the software Quantum GIS v. 2.14.5 following Calegari et al. (2016). Total genomic DNA was isolated through the DNeasy Blood \& Tissues Kit (QIAGEN ${ }^{\circledR}$, Hilden, Germany). The mitochondrial gene 16S and the nuclear SH3PX3 were amplified with the primers 16SAR and 16SBR (Palumbi et al. 1991), and SH3PX3-F461 and SH3PX3-R1303 for first step of the nested PCR, and SH3PX3-F532 and SH3PX3-R1299 for the second PCR (Li et al. 2007). The polymerase chain reaction (PCR) was performed in $25 \mu \mathrm{l}$ of $10 \mu \mathrm{M}$ of each primer, $1 \times$ Master Mix Kit (QIAGEN ${ }^{\circledR}$, Hilden, Germany), and ca 40 ng of DNA. The amplicon was purified and sequenced in both directions at Funcional Bioscience ${ }^{\circledR}$, Inc. facility (WI, USA). The consensus sequences were edited and generated through program Geneious $^{\circledR} 6.0 .5$ (http://www.geneious.com) for deposition in GenBank.

\section{Results}

New record. Spinipterus acsi, UFRGS 21671, 1 specimen (also tissue sample preserved), male, $37.1 \mathrm{~mm} \mathrm{SL}$, Cachimbo Creek, tributary to Bauana Branco, Juruá River, upper Amazon basin, Carauari, Amazonas, Brazil, $05^{\circ} 09^{\prime} 57^{\prime \prime} \mathrm{S}, 067^{\circ} 16^{\prime} 20^{\prime \prime} \mathrm{W}$ (Fig. 2), Vinicius A. Bertaco, Tiago P. Carvalho and Nilton Leite, 16 June 2008.
Identification. Spinipterus acsi was described and distinguished from all members of Auchenipteridae based on the following diagnostic characters (Akama and Ferraris 2011): pectoral-fin spine with 4 rows of serrations (Fig. 3); lateral margin of skull roofing bones ornamented with a single row of spines; groove along dorsal midline posterior to dorsal fin, which accommodates the entire dorsal-fin spine and fin rays. The new specimen here recorded from the Juruá river basin shares all aforementioned distinctive features and is identified as Spinipterus acsi by both external morphological features and color pattern.

Spinipterus acsi, UFRGS 21671 (tissue 6598), nontype vouchered specimen, genseq-4 SH3PX3, GenBank Accession Number: MF595442; and genseq-4 16S, GenBank Accession Number: MF595171.

Remarks. The specimen collected in the Juruá River was compared to the holotype of Spinipterus acsi (ANSP 178209). The comparative morphological analysis revealed that the holotype of $S$. acsi has 3 rows of serration along anterior and anterolateral margins of the dorsal-fin spine instead of 4 rows as previously reported by Akama and Ferraris (2011) (Fig. 4), which also represents a diagnostic feature of Spinipterus within Auchenipteridae and is shared by the newly discovered specimen. Morphometric data for the holotype and the newly discovered specimen of $S$. acsi are shown in Table 1. 


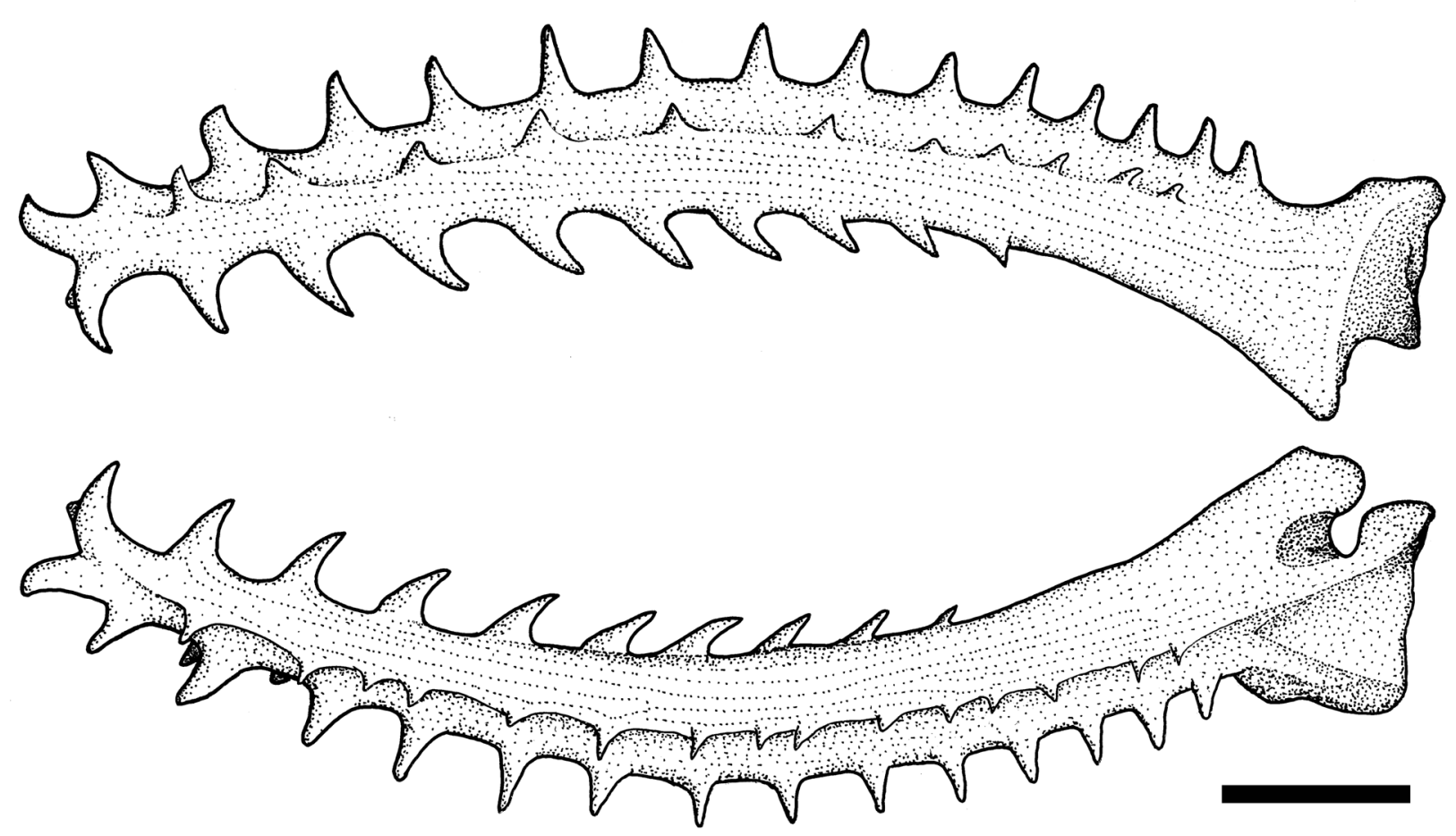

Figure 3. Dorsal (above) and ventral (below) views of the right pectoral-fin spine of Spinipterus acsi, holotype, ANSP 178209, based on high resolution $\mathrm{x}$-ray computed tomography (CT scan) showing 4 rows of spines. Scale bar $=1 \mathrm{~mm}$.

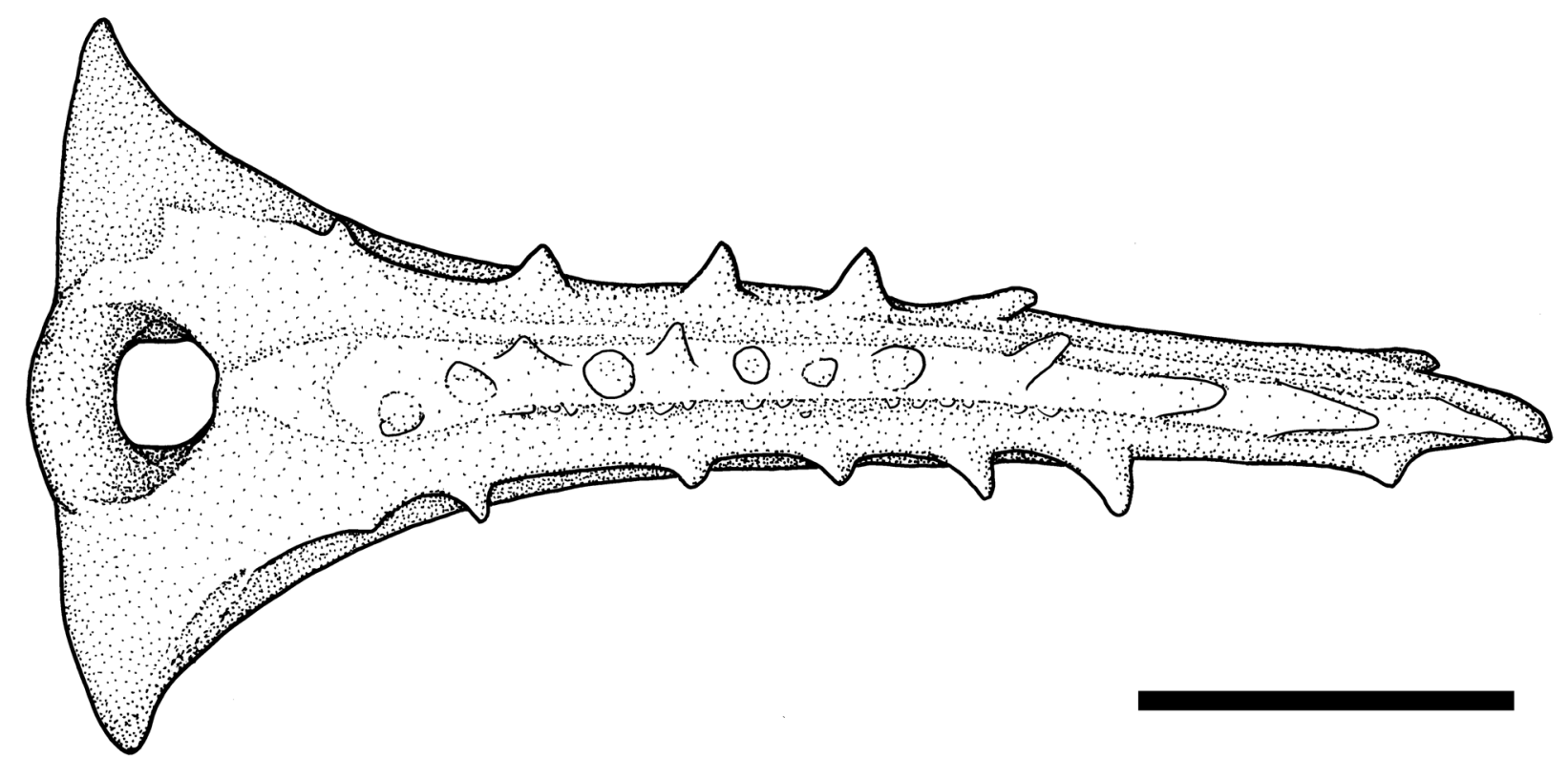

Figure 4. Dorsal view of the dorsal-fin spine of Spinipterus acsi, holotype, ANSP 178209, based on high resolution x-ray computed tomography (CT scan) showing 3 rows of spines. Scale bar $=1 \mathrm{~mm}$.

\section{Discussion}

Spinipterus acsi is easily recognizable by its body shape, especially by the dorsal- and pectoral-fin serrations, and by a row of well-developed spines along the lateral margins of the dorsal surface of the head. Thus, confusion with remaining species of Auchenipteridae is unlikely. When describing the new and unusual spiny auchenipterid Spinipterus, Akama and Ferraris (2011) had already drawn attention to how the biodiversity of small creeks and headwaters of the Amazon basin is poorly known, even in some relatively well explored areas. The discovery of a second specimen of Spinipterus acsi in a distinct drainage of the Amazon basin, representing the first record for Brazil, along with the known existence of three additional undescribed species, reinforce the assertion about the poor knowledge of biodiversity of fishes, particularly auchenipterids due to the difficulty in accessing their microhabitat.

The extinction risk of Spinipterus acsi has not been assessed for the IUCN Red List or the Brazilian Ministry of Environment (MMA/ICMBio). This new record extends its geographic distribution to a distance of about $1,900 \mathrm{~km}$ by river from the type locality (Fig. 2). Although 
this species seems to be naturally rare, additional collecting efforts should be conducted in order to reveal a more realistic geographic distribution before its extinction risk can be properly assessed.

Table 1. Morphometric data of Spinipterus acsi from the Juruá River, Brazil (UFRGS 21671), and the comparative data of the holotype (ANSP 178209) transcribed from Akama and Ferraris (2011).

\begin{tabular}{lll}
\hline Measurements & Juruá specimen & Holotype \\
\hline Standard length (mm) & 37.1 & 32 \\
\hline Percent of standard length & & \\
Predorsal length & 34.8 & 33.1 \\
Prepectoral length & 24.2 & 23.4 \\
Head length & 25.2 & 24.6 \\
Body depth & 20.9 & 22.8 \\
Body width & 28.2 & 28.1 \\
Upper gill membrane distance & 23.6 & 22.6 \\
Dorsal-fin base length & 11.1 & 12.8 \\
Dorsal-fin spine length & 13.5 & 12.5 \\
Cleithral process length & 20.8 & 24 \\
Pectoral-fin spine length & 23.0 & 23.4 \\
Anal-fin base & 20.7 & 20.2 \\
Caudal peduncle length & 14.2 & 14.7 \\
Caudal peduncle depth & 12.5 & 12.1 \\
\hline Percent of head length & & \\
Mouth width at rictus & 59.5 & 67.4 \\
Snout length & 31.6 & 36 \\
Eye diameter horizontal & 18.9 & 19.8 \\
Bony interorbital & 56.9 & 58.9 \\
Internarial length & 21 & 17.8 \\
\hline
\end{tabular}

\section{Acknowledgements}

We thank Luiz R. Malabarba and Juliana Wingert (UFRGS) for their assistance with the loan of the material; Tiago P. Carvalho (UFRGS) for indicating the existence of this specimen; Cristina Bürnheim (UFAM) for details of the locality; and Cristina Bürnheim, Vinicius A. Bertaco, Tiago P. Carvalho and Nilton Leite for collecting the specimen. We are grateful for financial support to the Coordenação de Aperfeiçoamento de Pessoal de Nível Superior (CAPES, Postdoctoral fellowship, process \#88887.137808/2017-00 to BBC) and Conselho Nacional de Desenvolvimento Científico e Tecnológico (CNPq process \# 306455/2014-5 to RER).

\section{Authors' Contributions}

$\mathrm{BBC}$ and $\mathrm{AA}$ examined and identified the specimen; $\mathrm{BBC}$ prepared the map, Figure 1, and took measurements; RR calculated geographical distance between localities along the river and prepared the schematic Figures 3 and 4. All authors wrote, revised, finalized, and approved the manuscript.

\section{References}

Akama A, Ferraris Jr CJ (2011) Spinipterus, a new genus of small, spiny catfish (Siluriformes: Auchenipteridae) from the Peruvian Amazon. Zootaxa 2992: 52-60.

Birindelli JLO (2014) Phylogenetic relationships of the South American Doradoidea (Ostariophysi: Siluriformes). Neotropical Ichthyology 12 (3): 451-564. https://doi.org/10.1590/1982-0224-20120027

Calegari BB, Reis RE, Vari RP (2014) Miniature catfishes of the genus Gelanoglanis (Siluriformes: Auchenipteridae): monophyly and the description of a new species from the upper rio Tapajós basin, Brazil. Neotropical Ichthyology 12 (4): 699-706. https://doi.org/10.1590/ 1982-0224-20130233

Calegari BB, Delapieve ML, Sousa LM (2016) Geographical distribution maps tutorial. Boletim, Sociedade Brasileira de Ictiologia 118: 15-30.

Eschmeyer WN, Fricke F, van der Laan R (2018) Catalog of Fishes: Genera, Species, References. http://researcharchive.calacademy.org/ research/ichthyology/catalog/fishcatmain.asp. Accessed on: 201806-01.

Ferraris CJ Jr, Vari RP (1999) The South American catfish genus Auchenipterus Valenciennes, 1840 (Ostariophysi: Siluriformes: Auchenipteridae): monophyly and relationships, with a revisionary study. Zoological Journal of the Linnean Society 126: 387-450. https://doi. org/10.1111/j.1096-3642.1999.tb00156.x

Li C, Ortí G, Zhang G, Lu G (2007) A practical approach to phylogenomics: the phylogeny of ray-finned fish (Actinopterygii) as a case study. BMC Evolutionary Biology 7 (44): 1-11. https://doi. org/10.1186/1471-2148-7-44

Lundberg JG, McDade L (1986) A redescription of the rare Venezuelan catfish Brachyrhamdia imitator Myers (Siluriformes: Pimelodidae) with a phylogenetic evidence for a large intrafamilial lineage. Notulae Naturae 463: 1-24. https://doi.org/10.1635/00973157(2002)152[0075:PNGARO]2.0.CO;2

Palumbi SR, Martin A, Romano S, Mcmillan WO, Stice L, Grabowski G (1991) The Simple Fool's Guide to PCR. University of Hawaii Press, Honolulu, 24 pp. 